\title{
Analysis and Countermeasures of Automation Specialty Construction in Our University Under the Background of Engineering Education Professional Certification
}

\author{
Jialin Wang and shengmao Yan* \\ College of Electronic Engineering, Naval Univ.of Engineering, Wuhan 430033, China \\ *corresponding author.email:5616729@qq.com
}

\begin{abstract}
Engineering education professional certification is an internationally accepted quality assurance system for engineering education. Its core is to ensure that engineering graduates meet the established quality standards recognized by the industry. It is a qualification evaluation standard oriented by training objectives and graduation export requirements. Engineering education professional certification has become a new wind vane for Chinese universities. There are many similarities and distinctive features between automation major of our university and that of local universities. At present, there is no research on the comparison between the accreditation evaluation standard of automation engineering education specialty and the construction status of Automation Specialty in our university. This paper studies the accreditation evaluation standards and requirements of automation engineering education specialty, and conducts in-depth comparative analysis and research with the existing training objectives and curriculum system setting, teacher team configuration, engineering ability training and practice of students, graduation design, etc., and puts forward the strategies and methods to solve the construction problems of Automation Specialty, so as to promote the education and teaching reform of Automation Specialty in our university. It provides the basis for strengthening engineering practice education, further strengthening the relationship between the training of students and the post, and improving the adaptability of students.
\end{abstract}

Keywords: teaching reform, engineering education professional certification, the design and innovation of the experimental mode, automation specialty construction

\section{INTRODUCTION}

China's higher education professional certification originated from the end of the 20th century, mainly drawing on the quality certification and evaluation system of western countries such as Britain and the United States.After nearly 20 years of development and improvement, many schools and majors have passed the professional certification and accumulated relatively rich experience.China has gradually carried out certification work in engineering specialty, and has become a preparatory member of Washington Agreement in $2013^{[1]}$. The agreement is an international organization for mutual recognition of qualifications. Its purpose is to promote cross-border practice of engineering personnel through multilateral recognition of engineering education qualifications and engineering personnel practice qualifications, so as to clarify the development direction of China higher engineering education professional certification.The quality of engineering personnel training provides an important guarantee ${ }^{[2]}$.In 2014, China Engineering Education Professional Certification Association revised the requirements of China\&apos;s general standards for engineering education professional certification. In terms of standards, China\&apos;s professional certification is gradually in line with international standards.In June 2016,
China became a full member of the Washington Agreement, which to a certain extent indicates that the quality and certification organization and procedures of China\&apos;s engineering education have been recognized by the international community. It is an important milestone in the history of China\&apos;s higher education, and marks that China\&apos;s engineering education and its quality assurance system have entered a new historical stage.Based on the requirements of the general standards of Engineering Education Accreditation in China, the requirements of engineering professional certification in China are mainly from four aspects: input, process, output and continuous improvement. The input includes teachers, teaching facilities, institutional support, funds and other operating conditions; the process includes curriculum system design, teaching quality management and evaluation, professional structure design, etc.; and the output is studentsThrough the evaluation and feedback of input, process and output, the purpose of professional continuous improvement is achieved.China engineering professional certification generally from the training objectives, Graduate requirements, curriculum system, students, teaching staff, support conditions and continuous improvement of seven aspects of the specific analysis of the application.The training goal is the overall description of the professional and professional achievements that students can achieve in about 5 years after graduation, 
which should conform to the orientation of the school and meet the needs of social and economic development.Graduation requirements include engineering knowledge, ability to analyze problems, ability to design / develop solutions, research ability, ability to use modern tools, engineering and society, environment and sustainable development, professional norms, team cooperation ability, communication ability, project management ability, lifelong learning and so on..The course system is the necessary and sufficient condition to support the achievement of graduation requirements. If the course support is not enough, it will affect the achievement of graduation requirements. The course does not undertake the supporting task, which means that the course does not need to be set up.These three aspects are the foundation and key of the current engineering education certification audit, and the last four aspects are the condition guarantee. Only when the training objectives, graduates requirements and curriculum system are formulated correctly and reasonably, and the logical relationship is clear, the other four aspects can better play their roles and ensure that the training of engineering professionals meets the social needs ${ }^{[3]}$.

\section{TRAINING OBJECTIVES OF AUTOMATION MAJOR}

This major cultivates and cultivates application-oriented senior engineering and technical personnel who meet the needs of socialist modernization construction, develop morally, intellectually, physically, aesthetically and laboriously, and coordinate and unify their quality, ability and knowledge.Graduates should have the basic knowledge and professional knowledge related to railway enterprises and local automation equipment manufacturing enterprises in the field of automation, have certain ability to acquire and comprehensively use knowledge, and have strong engineering practice ability, social responsibility and professional ethics.Five years after graduation, the students of this major should achieve the following training objectives ${ }^{[4]}$ : 1. All round development of morality, intelligence, physique, beauty and labor, with strong sense of social responsibility and professional ethics, good scientific and humanistic quality, and be able to consider the influence of social, legal, environmental and sustainable development factors in engineering practice; 2 . Master the relevant self-development of automation major.However, with scientific knowledge, professional foundation and professional theoretical knowledge, and be able to analyze the problems of complex automation engineering in railway enterprises and local enterprises, propose solutions and solve practical engineering problems; training objective 3: have good foreign language application ability and international vision, have the ability to comprehensively use modern scientific knowledge, and be able to carry out work creatively ;Training objective 4: to have the awareness of continuous learning and strong ability of self-learning and lifelong learning; training objective 5: to have the professional technical ability of engineers, and be competent for the production practice in the fields of locomotive control system manufacturing and maintenance, electrical automation equipment manufacturing, automatic production line, automatic instrument and product production and artificial intelligence and teaching and scientific research.

Under the background of engineering education professional certification, at present, more than 40 local colleges and universities have passed the professional certification of automation specialty. By implementing the concept of "student-centered, output oriented, continuous improvement", the automation specialty of these colleges and universities revised the training objectives, optimized the curriculum system, deepened the classroom reform, and improved the evaluation mechanism, so as to set up the talent training program and curriculum system.It is more in line with the school running orientation of the University, in line with the requirements of regional economic development for applied senior technical talents, with distinctive characteristics of the times and specialty. The professional school running level plays a demonstration and leading role in the same type of colleges and universities, and achieves the good effect of continuously improving the quality of talent training.At the same time, the quality assurance system of engineering education has been internationally recognized, and the results of engineering education certification will be recognized by other member states. Graduates who have passed the certification will enjoy the same treatment as domestic graduates when they apply for engineer qualification in relevant countries.It can be seen that the professional certification of engineering education plays an important role in training graduates with strong competitiveness and high comprehensive quality as well as professional development.

\section{CONSTRUCTION STATUS OF AUTOMATION SPECIALTY IN OUR UNIVERSITY}

The traditional automation specialty is based on the principle of automatic control, with electronic technology, computer technology, sensor and detection technology as the main technical means to control various automatic devices and systems. It has the characteristics of wide coverage and large level span.In recent ten years, with the development of computer technology and artificial intelligence technology, the connotation of automation specialty has changed a lot. Especially at present, artificial intelligence technology is widely used in intelligent perception and information processing, intelligent command and control assistant decision-making, life simulator, human physical skills and intelligence, and these fields are the important equipment development Point field and direction. The automation specialty of our university is closely related to artificial intelligence. The development of artificial intelligence and the application of equipment put forward new requirements for the construction of automation specialty and personnel training, which urgently requires the construction of 
automation specialty and personnel training to adapt to the development of science and technology. At the same time, the automation specialty of our university has no clear industry background, and the export orientation of talent training is broad. The problem is that the development direction of specialty construction is not clear, and the specialty characteristics are not enough ${ }^{[5]}$. How to contact the equipment development and the future demand for talents, find out the development direction and growth point of specialty construction is the automation specialty construction must be solved under the current situation the problem.

\section{MAIN RESEARCH CONTENTS AND INNOVATION POINTS}

\subsection{Research contents}

(1) Referring to the general idea of training objectives and curriculum system in national engineering education accreditation standards for automation majors, this paper compares and analyzes whether the professional positioning and talent training objectives of Automation Specialty in our university are scientific and reasonable, analyzes whether the curriculum system in the existing training programs can meet the requirements of certification standards, and studies and gives suggestions for curriculum system setting adjustment; (2) According to the standard requirements for the allocation of teaching staff in the professional certification of standard engineering education, this paper analyzes the current situation and gap of the construction of the teaching staff of the automation specialty in our university, studies and puts forward the countermeasures and suggestions for improving the construction level of the teaching staff ${ }^{[6]}$;

(3) The requirements of engineering education certification standards for automation majors on engineering ability of students majoring in automation and the status quo of engineering practice ability training of automation majors in our university are compared and analyzed and countermeasures are studied;

(4) The requirements of engineering education certification standards for automation majors on graduation design and other practical links are compared and analyzed with the graduation design topic selection, process management, tutor guidance and defense of automation major in our university.

\subsection{Innovation points}

(1) Combined with the actual situation of automation major in our university, this paper studies the training objectives and curriculum system requirements of engineering education accreditation standard for automation specialty, and compares it with the existing training objectives and curriculum system of Automation Specialty in our university, and puts forward talent training programs and courses with distinctive characteristics of the times and major, which are more in line with the school running orientation of the University Suggestions on the setting of process system.

(2) This paper makes a comparative analysis of the requirements of engineering education professional certification on the teaching staff of automation specialty, the allocation of teachers team and the existing problems of Automation Specialty in our university. On this basis, the paper puts forward the construction strategy of teachers team, which provides the basis for the introduction of talents and the cultivation of teachers ${ }^{[7]}$; (3)This paper makes a comparative study on the requirements of engineering education accreditation standards of automation majors on engineering ability of students majoring in automation and the status of engineering ability training and practice of automation majors in our university, analyzes the existing problems, and gives the ways and evaluation system to improve the engineering ability training and practice of students;

(4) This paper studies the requirements of engineering education accreditation standards for automation majors on graduation design, compares and summarizes the experience and main problems in the topics selection, process management, equipment and tutor allocation, defense and other links of automation major in our university, and puts forward relevant measures to improve the quality of graduation design.

\subsection{Research ideas and methods}

The overall idea is to study and analyze the standards and requirements of the training objectives and curriculum system, teaching staff, engineering ability and graduation design of Automation Specialty in accordance with the general standards for engineering education professional certification in China, and also with the existing training objectives and curriculum system setting, the allocation of teaching staff, the cultivation and practice of students engineering ability. The graduation project and other indepth comparative analysis and research, combined with the development of artificial intelligence technology, the needs of the Navy and the characteristics of our automation specialty, the Countermeasures for the existing problems are studied, which mainly include four aspects: first, combining with the situation of " $\mathrm{x}+$ artificial intelligence" major test point of automation major in our university, the paper puts forward that it is more in line with the school orientation, in line with the development of naval equipment and future intelligence.The requirements of the war on talents, talent training programs and curriculum system with distinctive characteristics of the times and specialties are proposed.Second, combined with the ongoing introduction of civilian personnel, this paper puts forward targeted strategies for the construction of teaching staff, so as to provide the basis for talent introduction and teacher training.The third is to give the way and evaluation system to improve the students engineering ability training and practice.Fourth, put forward the relevant measures to improve the quality of graduation project. 
The research methods were as follows

(1) Through extensive research, collecting and sorting out data, accumulating information resources, fully understanding and mastering the general standard requirements of engineering education professional certification in China, studying and analyzing the standards and requirements of engineering education professional certification on the training objectives and curriculum system, teaching staff, engineering ability and graduation design of automation specialty, so as to lay the foundation for the research of this subject.

(2) In this paper, the standards and requirements of Automation Specialty in the accreditation of engineering education specialty are compared, the existing problems and accumulated experience of Automation Specialty in our university are summarized, the overall research scheme is formulated, and the division of labor of the research group of each main research content is studied ${ }^{[8]}$.

(3) Combined with the development needs of artificial intelligence technology and considering the actual situation of automation major in our university, this paper puts forward some suggestions on the setting of talent training scheme and curriculum system which are more in line with the school orientation, with distinctive characteristics of the times and majors, targeted strategies for the construction of teaching staff, ways and evaluation system for improving students engineering ability training and practice, and improving graduation design quality related measures ${ }^{[9]}$

\section{CONCLUSION}

There are many similarities between the automation major of our university and that of local universities, especially in the aspects of training objectives and curriculum system requirements, the construction of professional teaching staff and the project of cultivating students.The certification requirements of automation engineering education specialty are the concentrated embodiment of the social needs of automation specialty, with distinct characteristics of the times and specialty.Therefore, combined with the characteristics of Automation Specialty in our university, the evaluation standards and requirements of automation engineering education specialty are studied, and compared with the existing training objectives and curriculum system setting, teacher team configuration, engineering ability training and practice of students, graduation design, etc., and the existing problems and deficiencies are analyzed and solved.The strategies and methods of construction problems provide the basis for promoting the education and teaching reform of Automation Specialty in our university, which is of great significance to carry out the construction of talent cultivation of automation specialty and improve the quality of talent training. The research results of the project can also provide useful reference for other similar professional construction and personnel training.

\section{REFERENCES}

[1] Jiaxing Ma,Keyu Chen,Xinyuan Shen, Yinhui Wang. Research on the Teaching Reform of the Course of Principles of Concrete Structure Design in the Background of Engineering Education Professional Certification[C]. Institute of Management Science and Industrial Engineering.Proceedings of 2020 International Conference on Education,Sport and Psychological Studies(ESPS 2020).Institute of Management Science and Industrial Engineering:(Computer Science and Electronic Technology International Society),PP.78-84,2020.

[2] Li G Q, Xiong H B. Engineering educational assessment and international professional accreditation [J]. Journal of Architectural Education in Institutions of Higher Learning, vol.22,no.1,PP.5-12,2013.

[3] Chen Y Q, Li T J, Zhu M B, et al. Discussion on the teaching model of "Mechanical Design" under the background of engineering education certification[J] China Electronic Education, 2015, 81(3):31-34 vol.81,no.3,PP.31-34,2015.

[4] Zhou J L, Cheng X M, Zhang D H, et al. Exploring the teaching model of material mechanics course oriented by engineering education certification [J]. University Education, 2019, 106 (4): 86-88. vol.106,no.4,PP.8688,2019 .

[5] Fang Y, Xiang G S, Xie S H, et al. Teaching Reform of Soil Mechanics Course based on the Theory of Professional Certification[J]. Journal of Anhui University of Technology (Social Sciences Edition), vol.137,no.4,PP.92-93,2017.

[6] Zheng X J, Xie Z Y, Hou X L. Research on teaching design of steel structure course based on international engineering certification requirements $[\mathrm{J}]$. Journal of Architectural Education in Institutions of Higher Learning, vol.27,no.3,PP.51-55,2018.

[7] Xia H C. Teaching reform and practice of concrete structure design principle course[J]. Journal of Architectural Education in Institutions of Higher Learning, 2019, 28 (1): 86-90. vol.28,no.1,PP.86-90,2019.

[8] Liu J P, Jia Z R, Shi Jun, et al. On three-dimensional teaching mode for concrete structure serial courses based on CDIO education ideas [J]. Journal of Architectural Education in Institutions of Higher Learning, 2011, 20 (5): 83-87. vol.20,no.5,PP.83-87,2011.

[9] Liu J P, Jia Z R. Discussion on Blended Learning Model Based on Flipping Class [J]. Journal of Shandong University of Technology (Social Science Edition), 2016, 32 (6): 67-72. vol.32,no.6,PP.67-72,2016. 